\title{
Phytochemical screening and antioxidant activity of Melastoma malabathricum and Chromolaena odorata by DPPH radical scavenging method
}

\author{
${ }^{1}$ Ismail, N.H., ${ }^{1, *}$ Amira, N.H., ${ }^{1,2}$ Latip, S.N.H.M., ${ }^{1}$ Zain, W.Z.W.M., ${ }^{1}$ Aani, S.N.A. and \\ ${ }^{3}$ Aziman, N.A. \\ ${ }^{1}$ Faculty of Plantation and Agrotechnology, Universiti Teknologi MARA, Jasin Campus, 77300, Melaka, \\ Malaysia \\ ${ }^{2}$ Sustainable Crop Protection Research Group, Faculty of Plantation and Agrotechnology, \\ Universiti Teknologi MARA, 40450, Shah Alam, Selangor, Malaysia \\ ${ }^{3}$ Alliance of Research \& Innovation for Food (ARIF), Faculty of Applied Sciences, Universiti Teknologi \\ MARA, Kuala Pilah Campus, 72000 Kuala Pilah, Negeri Sembilan, Malaysia
}

\begin{abstract}
Article history:
Received: 16 April 2021

Received in revised form: 1 June 2021

Accepted: 25 October 2021

Available Online: 26

November 2021
\end{abstract}

\section{Keywords:}

Phytochemical screening,

Antioxidant,

Chromolaena odorata,

Melastoma malabathricum

DOI:

https://doi.org/10.26656/fr.2017.5(S4).006

\begin{abstract}
Melastoma malabathricum and Chromolaena odorata are classified under broad-leaved weeds that are widely spread in the open land area. Melastoma malabathricum is commonly known as "senduduk", and C. odorata is locally known as "Pokok Kapal Terbang". Both weeds are categorized as potential weeds as they have high nutritive value and are rich in chemical compounds. This study aimed to determine their chemical constituents and possible potential for antioxidant activity as these weeds have been reported to possess antioxidant properties. Screening of the plants was performed using standard methods and revealed the existence of various secondary metabolites such as saponins, terpenoids, phenols, tannins, and flavonoids of both weed extracts. Antioxidant activity was validated by the DPPH radical scavenging assay of M. malabathricum and $C$. odorata crude ethanol extract. The IC50 values for the percentage radical scavenging effects for the extracts were determined. The IC50 value of M. malabatrichum extract was $81.116 \mu \mathrm{g} / \mathrm{mL}, C$. odorata was $312.903 \mu \mathrm{g} / \mathrm{mL}$, Vitamin C was $31.023 \mu \mathrm{g} / \mathrm{mL}$ and BHA was $71.521 \mu \mathrm{g} / \mathrm{mL}$ respectively. The study showed that the antioxidant activity of $M$. malabatrichum was more potent and better than C. odorata.
\end{abstract}

\section{Introduction}

Weeds are recognized as the unwanted and undesirable plant that grows at an open land area (Zimdahl, 2007). There are several morphological types' characteristics of weeds such as broadleaved weeds, grasses, sedges, and ferns (Barnes and Chan, 1990). Traditionally to treat human diseases, plant organic compounds of primary and secondary metabolite has been used due to their efficacy potential and have been confirmed safe for animal and human use. Some weeds are known as medicinal plants that have allelochemicals made up of secondary metabolites (Badmus and Afolayan, 2012). The chemical compounds that come from plants are a result of normal metabolic activities. These chemical compounds are classified into primary and secondary metabolites, and the secondary metabolites and other chemical constituents contribute to their medicinal value (Parivuguna, 2008). Melastoma malabathricum and $C$. odorata are chosen as they have chemical constituents that can contribute to their potential.

Phytochemicals that can be found in plants as plant chemicals have protective and preventive properties against diseases (Breslin, 2017). The presence of numerous bioactive chemicals in plants has been revealed by many studies including alkaloids, steroids, flavonoids, phenols, glycosides, and saponins (Banothu et al., 2017). They play a very important aspect in the plant's protection such as antibacterial, antiviral, antifungal, and insecticidal agents (Hajlaoui et al., 2009). Melastoma malabathricum and C. odorata are reported to have benefits and potential. Melastoma malabathricum is used as a folk medicine for the treatment of dysentery, haemorrhoids, diarrhoea, wounds, leucorrhoea, and cuts mainly in India, Malaysia, Indonesia, and other parts of the world (Joffry et al., 2012). Melastoma malabathricum also showed bioactivity as an antibacterial (Choudhury et al., 2011), 
antifungal (Johnny et al., 2010), antiviral (Lohézic-Le Dévéhat et al., 2002), anticoagulant (Manicam et al., 2010), wound healing (Anbu et al., 2008), antidiarrheal (Sunilson et al., 2009), anti-inflammatory (Zakaria et al., 2006) and antioxidant (Susanti et al., 2007) which have been experimentally validated. Allelochemical that can be derived from M. malabathricum such as rutin hydrate, quercetin hydrate, nobotanin $\mathrm{B}$, malabathrins $\mathrm{B}$, malabathrins $\mathrm{C}$, malabathrins $\mathrm{D}$, strictinin, casuarictin, nobotanin $\mathrm{G}$, nobotanin $\mathrm{H}$, and nobotanin $\mathrm{J}$ (Yoshida et al., 1992; Azahar et al., 2020). While for C. odorata, it is used as a treatment of leech bites, burns, soft tissue injuries, and skin infections (Phan et al., 2001). Chromolaena odorata also showed bioactivity as an antibacterial (Atindehou et al., 2013), antifungal (Naidoo et al., 2011), anti-inflammatory (Pandith et al., 2013), anticancer (Kouamé et al., 2013), antiplasmodial (Ezenyi et al., 2014), antidiabetic (Onkaramurthy et al., 2013), and antioxidant (Boudjeko et al., 2015). Allelochemical that can be derived from $C$. odorata such as quercetin-4 methyl ether, aromadendrin-4'-methyl ether, taxifolin-7methyl ether, taxifolin-4'-methyl ether, transcaryophyllene, $\delta$-cadinene, $\alpha$ copaene and caryophyllene oxide (Haji Jasnie et al., 2009; Chakraborty et al., 2011).

Every phytochemical compound has its potential. Saponins were reported to have toxicity towards insects (insecticidal activity), parasite worms (anthelmintic activity), molluscs (molluscicidal), fish (piscicidal activity), antifungal, antiviral, and antibacterial activities are well documented (Francis et al., 2002). For tannins, it was reported to have antimicrobial effects (Stanley et al., 2014), and the terpenoids showed the effect on the plant, fungi, and plant growth (Ling et al., 2003). Flavonoids involve in the inactivation of microbial adhesins, enzymes, disrupting microbial membranes, and cell envelope transport proteins (Maji et al., 2010). Flavonoids are also extensively distributed in plants and have been discovered to possess many biological properties such as antioxidant, free radical scavenging, anti-inflammatory, and anticarcinogenic properties (Eze et al., 2013). The secondary metabolites reported being potent free radical scavengers that come from phenolic and flavonoids of plants. They are found in all parts of plants such as leaves, seeds, fruits, roots, and bark (Tiwary et al., 2015). Phenolic compounds and flavonoids have been reported to be relatable with antioxidative action in biological systems, acting as scavengers of singlet oxygen and free radicals (Jørgensen et al., 1999).

With the phytochemical's constituents in the weeds, it can be related ability for natural antioxidants. Natural antioxidants or phytochemical antioxidants are the secondary metabolites of plants (Walton and Brown,
1999). Antioxidants can be obtained synthetically or naturally. The antioxidant capacity can be measured in a rapid, simple, and inexpensive method by the use of the free radical, 2, 2-Diphenyl-1 picrylhydrazyl (DPPH). This method is widely used to test the compounds' potential to perform as free radical scavengers or hydrogen donors and antioxidant activity evaluation (Kirtikar and Basu, 2006). The antioxidant is a bioactive substance, free radical scavengers, enzyme inhibitors, electron donors, and metal chelators that prevent the oxidation of harmful chemicals (Pisoschi et al., 2016). The DPPH radical assay that was used in this study is one of the few stable organic nitrogen radicals, which carry a deep purple colour. This assay measures the ability of antioxidants reduction toward DPPH. The ability can be assessed through electron spin resonance (ESR) spectrometry or by measuring absorbance decrease value (Prior, 2005). The DPPH assay is a marginal reaction pathway that is expressed to be mainly dependent on an electron transfer (ET) reaction, and hydrogen-atom abstraction (Huang et al., 2005). DPPH radicals are free radicals with high reactivity at room temperature.

The free radical scavenging activity of the extracts was measured based on the ability to scavenge the DPPH. The mechanism of radical scavenging is hydrogen donors and the high reactivity is caused by the delocalization of electrons around the molecules. When the DPPH radical is reacted with a substance that donates a hydrogen atom, DPPH radical is reduced into a nonradical DPPH. In the assay, this reaction is indicated by solution decolourization. It changes its colour from purple to yellow (Putri and Fatmawati, 2019). Substances that can perform this reaction are considered antioxidants or radical scavengers (Dehpour et al., 2009). Antioxidative compounds (vitamin C, E, A, selenium, and carotenoids), ascorbic acid (Vitamin C) show a very strong intensity of antioxidative activities (Kaczmarski et al., 1999). In most food industries, synthetic antioxidants such as butylated hydroxyanisole (BHA), butylated hydroxytoluene (BHT), tertiary butyl hydroquinone (TBHQ), propyl gallate (PG), and others are used to prevent the rancidity of processed foods (Bhuiyan et al., 2009)

Melastoma malabatrichum from Melastomataceae family and $C$. odorata from Asteraceae family was chosen to prove that these weeds have potential to be commercialized and can benefits to human through several bioactivities that can be done. Both weeds were selected to study their phytochemical constituents which can prove their contribution to several bioactivities and to determine the antioxidant activity by the DPPH scavenging method to possess antioxidant properties in these weeds. Thus, this study was carried out to screen 
the phytochemicals present in the leaf and to determine the antioxidant potentials of M. malabathricum and C.odorata and evaluate which weeds have better antioxidant activity.

\section{Materials and methods}

\subsection{Preparation of extracts}

Melastoma malabathricum and C. odorata leaves washed under running tap water, dried under the shaded area, then were dried at $50^{\circ} \mathrm{C}$ for $24 \mathrm{hrs}$ using the oven. The dried samples were prepared into powder using a mechanical blender. One hundred grams of powders of selected weed leaves were soaked in $500 \mathrm{~mL}$ of $95 \%$ ethanol at room temperature $\left(27 \pm 1^{\circ} \mathrm{C}\right)$ from day 1 to day 7. The extracts were then filtrated through Whatman No. 1 filter paper before evaporating the residual solvent using a rotary evaporator. The crude extracts were kept at $4^{\circ} \mathrm{C}$ in a chiller until used.

\subsection{Phytochemical screening}

Phytochemical screening of selected weeds leaves were tested with modification for the presence of saponins, terpenoid, phenolic, tannins, and flavonoid. The qualitative results were expressed as $(+)$ for the presence and (-) for the absence of phytochemicals. Test for saponin, about $0.5 \mathrm{~g}$ of each weed powder was shaken vigorously with $5 \mathrm{~mL}$ of distilled water in a test tube. The formation of stable foam was taken as an indication of the presence of saponins (Treas and Evans, 2002). Test for terpenoid, about $0.5 \mathrm{~g}$ of each weed powder was added with $2 \mathrm{~mL}$ of chloroform, and $2 \mathrm{~mL}$ of concentrated $\mathrm{H}_{2} \mathrm{SO}_{4}$. The reddish-brown colour was taken as an indication of the presence of terpenoid (Richardson, 1990). Test for phenolic, about $0.5 \mathrm{~g}$ of each weed powder was added with 5:5 of Methanol: distilled water, mixed with 2 drops $2 \% \mathrm{FeCl}_{3}$. The blue, green or purple colour was taken as an indication of the presence of phenols (Richardson, 1990). Test for tannin, about $0.5 \mathrm{~g}$ of each weed powder, was added with $0.5 \mathrm{~mL}$ ethanol, $3.5 \mathrm{~mL}$ deionized water and a few drops of $5 \%$ $\mathrm{FeCl}_{3}$. The green or blue colour was taken as an indication of the presence of tannin (Richardson, 1990). Test for flavonoid, about $0.5 \mathrm{~g}$ of each weed powder, was added with $4 \mathrm{~mL}$ ethanol and a few drops of $10 \%$ $\mathrm{FeCl}_{3}$ solution. The green or blue colour was taken as an indication of the presence of flavonoids (Brain and Turner, 1975).

\subsection{Determination of antioxidant activity}

The antioxidant activity of both weed leaf extract was determined by its DPPH radical scavenging activity. The method with modification by Zhang and Xu in 2015 for DPPH free radical scavenging was used in this study.
$0.1 \mathrm{mM}$ solution of DPPH in methanol was prepared. Five different extracts concentrations of 100, 200, 300, 400 , and $500 \mathrm{ppm}$ were prepared at 517 abs by using a spectrophotometer. Vitamin C and BHA were used as standard controls (Dehpour et al., 2009). The percentage inhibition was calculated using the equation:

DPPH radical scavenging activity $(\%)=[($ Absorbance of control - Absorbance of the sample) / (Absorbance of control)] $\times 100$.

Half-maximal inhibitory concentration (IC50) values denote the concentration of the sample, which is needed to scavenge $50 \%$ of DPPH free radicals (Shekhar and Anju 2014).

\section{Results and discussion}

\subsection{Phytochemical screening}

The results of phytochemicals determine that phenolic and tannin were highly present for both weeds. Melastoma malabatrichum phytochemical test was highly present, followed by $C$. odorata (Table 1 ).

Table 1. Qualitative analysis of the phytochemicals of the leaves

\begin{tabular}{lcc}
\hline & M. malabatrichum & C. odorata \\
\hline Saponins & +++ & + \\
Terpenoids & +++ & +++ \\
Phenols & +++ & +++ \\
Tannins & +++ & +++ \\
Flavanoids & +++ & ++ \\
\hline
\end{tabular}

Saponins, terpenoids, phenols, tannins and flavonoids were present in both samples. Melastoma malabatrichum showed positive results on saponins, terpenoid, phenolic, tannins, and flavonoid's existence of $(3+)$. A similar result was obtained that revealed the presence of saponins, flavonoids, and tannin in $M$. malabatrichum leaves by Sulistyaningrum et al. (2018). This also has been proven by Sembiring et al., 2018 that saponins, terpenoids, tannins, and flavonoids are present in the M. malabatrichum leaves. Zakaria et al. (2006) also revealed the existence of saponin (1+), flavonoids $(2+)$, and tannins $(2+)$ in M. malabatrichum leaves. Danladi et al. (2015) reported with no saponin, $(3+)$ for tannins, $(3+)$ for phenols, $(1+)$ for terpenoid, and $(2+)$ for flavonoids. For $C$. odorata leaves, a similar result was also obtained that revealed the presence of saponins, terpenoid, tannins, and flavonoids by Fauzi et al. (2020). Odutayo et al. (2017), also revealed the existence of (1+) for saponins, $(2+)$ for terpenoids, $(2+)$ for flavonoids, $(1+)$ for tannins, and $(1+)$ for phenols. Previous studies confirmed the presence of some phytochemical constituents in the leaves of both weeds. Thus, this supports the present results with the presence of 
saponins, terpenoids, phenols, tannins and flavonoids in both weeds. With the present results that expressed with $(+)$ and (-), its contribution for the new findings with $(3+)$, shows the compound strongly present.

\subsection{Antioxidant activity}

The scavenging effect of $M$. malabatrichum and $C$. odorata with vitamin $\mathrm{C}$ and $\mathrm{BHA}$ were compared. On the DPPH radical, M. malabatrichum and C. odorata had significant scavenging effects with increasing concentration in the range of $100-500 \mathrm{ppm}$ when compared with Vitamin $\mathrm{C}$ and BHA. The DPPH activity of $M$. malabatrichum and $C$. odorata was found to increase in a dose-dependent manner. The $M$. malabatrichum and C. odorata at the used concentrations showed the potential effect of DPPH activity as a percentage of free radicals inhibition. Antioxidant assay of $M$. malabathricum and $C$. odorata leaves extracts displayed the ability to inhibit DPPH free radical formation by $93 \%$ at $300 \mathrm{ppm}$ concentration on $M$. malabathricum while the C. odorata by $79 \%$ at $500 \mathrm{ppm}$ concentration (Figure 1).

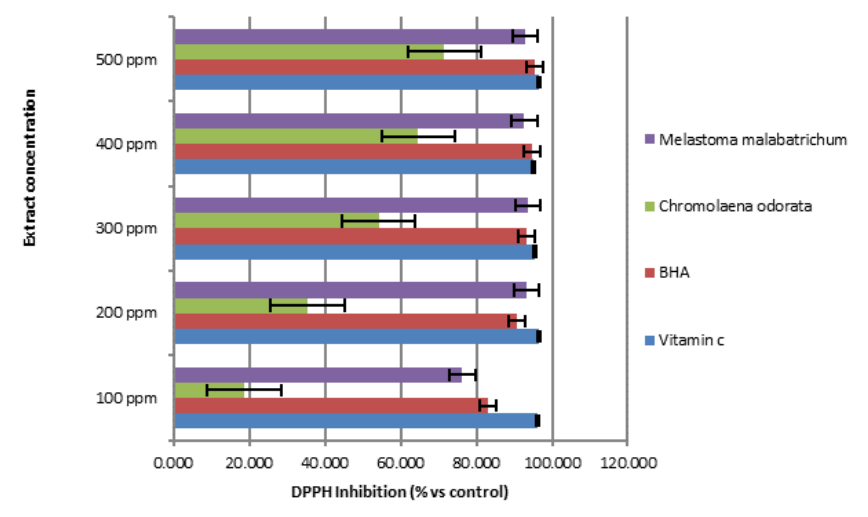

Figure 1. DPPH inhibition (\%)

Radical scavenging activity in this study showed the ability of a compound to scavenge free radicals which in turn prevents their toxic effect on the cell. The phenolic compound can scavenge free radicals by donating hydrogen atoms (Riaz et al., 2012). The results in (Figure 1) and (Table 2) show that M. malabatrichum has a DPPH radical inhibitory activity better than $C$. odorata. Vitamin $\mathrm{C}$ and BHA were noted as the reference antioxidant for this test. Scavenging of DPPH radical was found to rise with increasing concentration of the extracts.

The IC50 value $31.023 \mu \mathrm{g} / \mathrm{mL}$ obtained for Vitamin $\mathrm{C}$ and $71.521 \mu \mathrm{g} / \mathrm{mL}$ obtained for BHA as the standard was significantly lower than the values obtained for the extract of M. malabatrichum and C. odorata. The highest scavenging of extracts was observed with $M$. malabatrichum with an IC50 value of $81.116 \mu \mathrm{g} / \mathrm{mL}$ and as opposed to the IC50 value of standard Vitamin C and BHA which are well-known antioxidants (Table 3). The measured IC50 result indicates that the antioxidant activity of M. malabatrichum is greater than $C$. odorata. Therefore, the lower IC50 suggests that it has a higher antioxidant capacity. The result of the DPPH radical scavenging assay showed that $M$. malabatrichum extracts have a good DPPH scavenging effect and being the most active than $C$. odorata.

\begin{tabular}{cc}
$\frac{\text { Table 3. IC50 Value }(\mu \mathrm{g} / \mathrm{mL})}{2}$ \\
\hline \multicolumn{2}{c}{ IC50 $(\mu \mathrm{g} / \mathrm{mL})$} \\
\hline Vitamin C & 31.023 \\
BHA & 71.521 \\
M. malabatrichum & 81.116 \\
C. odorata & 312.903 \\
\hline
\end{tabular}

The results of antioxidant activity of $M$. malabatrichum leaves extracts showed that the higher concentration of the sample, the higher percentage of antioxidant activities. This is also due to the fact that the higher the concentration of extracts, the more concentrated the color of the sample, and the absorption of DPPH reduction is less than maximum. In this research, M. malabatrichum is known to have potent antioxidant properties, with the presence of flavonoids and tannins in the leaves. The result of the study also shows that the leaves extract of M. malabatrichum and $C$. odorata scavenged the free radicals by the DPPH method by a strong absorption band at 517 abs in the visible spectrum of deep violet colour. Free radicals are chemical compounds that have free electrons or unpaired electrons. Unpaired electrons are unstable which can easily bind to other molecules and unwanted reactions can be formed (Lingga, 2012). Unpaired electrons are the electrons in an atom that occur in an orbital alone. This means these electrons are not paired or occur as electron couples. Free radicals are when an atom or a molecule

Table 2. Percentage inhibition of DPPH free radical scavenging activity of $M$. malabathricum and $C$. odorata leaves extracts

\begin{tabular}{ccccc}
\hline Concentration (ppm) & $\begin{array}{c}\text { Vitamin C } \\
\text { (\% Inhibition) }\end{array}$ & $\begin{array}{c}\text { BHA } \\
\text { (\% Inhibition) }\end{array}$ & $\begin{array}{c}\text { C. odorata } \\
\text { (\% Inhibition) }\end{array}$ & $\begin{array}{c}\text { M. malabatrichum } \\
\text { (\% Inhibition) }\end{array}$ \\
\hline 100 & $96.04 \pm 0.92$ & $83.20 \pm 4.35$ & $35.37 \pm 15.37$ & $73.11 \pm 6.96$ \\
200 & $96.64 \pm 0.69$ & $90.71 \pm 3.97$ & $52.35 \pm 12.50$ & $93.24 \pm 0.72$ \\
300 & $95.70 \pm 0.66$ & $93.18 \pm 0.82$ & $52.35 \pm 12.50$ & $93.47 \pm 0.27$ \\
400 & $96.03 \pm 0.72$ & $94.58 \pm 1.17$ & $64.14 \pm 22.78$ & $93.24 \pm 0.68$ \\
500 & $97.08 \pm 0.25$ & $95.90 \pm 0.59$ & $79.86 \pm 10.57$ & $92.92 \pm 0.41$ \\
\hline
\end{tabular}

Values are presented as mean \pm S.D 
has this type of electron. The chemical elements having these electrons are highly reactive. This is because they tend to pair all their electrons to become stable and having an unpaired electron is unstable (Madhu, 2018). At higher concentrations, the plants' ability to scavenge DPPH radicals increases by increased percentage (\%) inhibition. In this study, a higher percentage of the leaves extracts exhibited the ability to scavenge DPPH radical used in a concentration-dependent manner as its \% Inhibition increased with the increase in concentration. Melastoma malabatrichum leaves compared with $C$. odorata revealed that the $M$. malabatrichum shows a strong activity as a radical scavenger using DPPH assay that indicates $M$. malabatrichum has a very strong ability to donate hydrogen when compared with standard, Vitamin C and BHA (Usunomena and Efosa, 2016). Our antioxidant result analyses of the leaves extract showed the presence of antioxidants and DPPH radical scavenging activity, which is denoted in phenolic compounds from plants and responsible for the radical scavenging activity (Oladipupo, 2014).

\section{Conclusion}

The study indicates that even though $M$. malabatrichum and $C$. odorata have been considered as an invasive weed, leaves of both weeds possess a valuable phytochemicals compound. The phytochemicals test (saponin, terpenoid, phenolic, tannin, and flavanoid) may relate to its importance in protective function, physical characteristics, and chemical characteristics of the weeds. The results also provide evidence that $M$. malabatrichum and $C$. odorata contain antioxidants properties. The results display that $M$. malabatrichum leaves have better antioxidant activity compared to $C$. odorata. Therefore, M. malabatrichum has a high potential to further study bioactivities.

\section{Conflict of interests}

The authors declare no conflicts of interest.

\section{Acknowledgements}

The present work was financially supported by the Fundamental Research Grant Scheme 600-IRMI/FRGS $5 / 3(245 / 2019)$. We are grateful to Dr Ab. Rahim bin Muda for the assistance with this present work.

\section{References}

Anbu, J., Jisha, P., Varatharajan, R. and Muthappan, M. (2008). Antibacterial and wound healing activities of Melastoma malabathricum linn. African Journal of Infectious Diseases, 2(2), 68-73. https:// doi.org/10.4314/ajid.v2i2.55063
Atindehou, M., Lagnika, L., Guérold, B., Strub, J.M., Zhao, M., Van Dorsselaer, A., Marchioni, E., Prevost, G., Haikel, Y., Taddei, C., Sanni, A. and Metz-Boutigue, M.H. (2013). Isolation and identification of two antibacterial agents from Chromolaena odorata L. active against four diarrheal strains. Scientific Research, 3(1), 115-121. https://doi.org/10.4236/aim.2013.31018

Azahar, N.F., Abd Gani, S.S., Zaidan, U.H., Bawon, P. and Halmi, M.I.E. (2020). Optimization of the Antioxidant Activities of Mixtures of Melastomataceae Leaves Species (M. malabathricum Linn Smith, M. decemfidum, and $M$. hirta) using a Simplex Centroid Design and Their AntiCollagenase and Elastase Properties. Applied Sciences, 10(19), 7002. https://doi.org/10.3390/ app10197002

Badmus, A. and Afolayan, A. (2012). Allelopathic potential of Arctotis arctotoides (Lf) O. Hoffm aqueous extracts on the germination and seedling growth of some vegetables. African Journal of Biotechnology, 11(47), 10711-10716.

Banothu, V., Neelagiri, C., Adepally, U., Lingam, J. and Bommareddy, K. (2017). Phytochemical screening and evaluation of in vitro antioxidant and antimicrobial activities of the indigenous medicinal plant Albizia odoratissima. Pharmaceutical Biology, 55(1), 1155-1161. https:// doi.org/10.1080/13880209.2017.1291694

Barnes, D.E. and Chan, L.G. (1990). Common weeds of Malaysia and their control. Malaysia: Ancom Berhad.

Bhuiyan, M.A.R., Hoque, M.Z. and Hossain, S.J. (2009). Free radical scavenging activities of Zizyphus mauritiana. World Journal of Agricultural Sciences, 5(3), 318-322.

Boudjeko, T., Megnekou, R., Woguia, A.L., Kegne, F.M., Ngomoyogoli, J.E.K., Tchapoum, C.D.N. and Koum, O. (2015). Antioxidant and immunomodulatory properties of polysaccharides from Allanblackia floribunda Oliv stem bark and Chromolaena odorata (L.) King and HE Robins leaves. BMC research notes, 8, 759. https:// doi.org/10.1186/s13104-015-1703-x

Brain, K.R. and Turner, D.T. (1975). Practical evaluation of phytopharmaceuticals. Bristol, United Kingdom: Wright-Scientechnica.

Breslin, A. (2017). The chemical composition of green plants. Retrieved from Sciencing website: https:// sciencing.com/chemical-composition-green-plants8336363.html

Chakraborty, A.K., Rambhade, S. and Patil, U.K. (2011). 
Chromolaena odorata (L.): An overview. Journal of Pharmacy Research, 4(3), 573-6.

Choudhury, M.D., Nath, D. and Talukdar, A.D. (2011). Antimicrobial activity of Melastoma malabathricum L. Assam University Journal of Science and Technology, 7(1), 76-78.

Dehpour, A.A., Ebrahimzadeh, M.A., Fazel, N.S. and Mohammad, N.S. (2009). Antioxidant activity of the methanol extract of Ferula assafoetida and its essential oil composition. Grasasy aceites, 60(4), 405-412. https://doi.org/10.3989/gya.010109

Eze, E.A., Oruche, N.E., Onuora, V.C. and Eze, C.N. (2013). Antibacterial screening of crude ethanolic leaf extracts of four medicinal plants. Journal of Asian Scientific Research, 3(5), 431-439.

Ezenyi, I.C., Salawu, O.A., Kulkarni, R. and Emeje, M. (2014). Antiplasmodial activity-aided isolation and identification of quercetin-4'-methyl ether in Chromolaena odorata leaf fraction with high activity against chloroquine- resistant Plasmodium falciparum. Parasitology Research, 113(12), 44154422. https://doi.org/10.1007/s00436-014-4119-y

Fauzi, N.A.M., Tan, N.F.M.S., Razak, A.H.A. and Mansur, S.A. (2020). Qualitative Phytochemical Analysis and Antibacterial Potential of Chromolena Odorata Leaves as affected by Soxhlet and Maceration Extraction. Journal of Advanced Industrial Technology and Application, 1(2), 38-48. https://doi.org/10.30880/ijie.2020.01.02.005

Francis, G., Kerem, Z., Makkar, H.P. and Becker, K. (2002). The biological action of saponins in animal systems: A Review. British Journal of Nutrition, 88 (6), 587-605. https://doi.org/10.1079/BJN2002725

Haji Jasnie, F. (2009). Biological activities and chemical constituents of Chromolaena odorata Malaysia: University of Malaya, MSc. Thesis.

Hajlaoui, H., Trabelsi, N., Noumi, E., Snoussi, M., Fallah, H., Ksouri, R. and Bakhrouf, A. (2009). Biological activities of the essential oils and methanol extract of tow cultivated mint species (Mentha longifolia and Mentha pulegium) used in the Tunisian folkloric medicine. World Journal of Microbiology and Biotechnology, 25(12), 22272238. https://doi.org/10.1007/s11274-009-0130-3

Huang, D., Ou, B. and Prior, R.L. (2005). The chemistry behind antioxidant capacity assays. Journal of Agricultural and Food Chemistry, 53(6), 1841-1856. https://doi.org/10.1021/jf030723c

Joffry, S.M., Yob, N.J., Rofiee, M.S., Affandi, M.M.R., Suhaili, Z., Othman, F., Md. Akim, A., Desa, M.N.M. and Zakaria, Z.A. (2012). Melastoma malabathricum (L.) Smith ethnomedicinal uses, chemical constituents, and pharmacological properties: A review. Evidence-Based Complementary and Alternative Medicine, 2012, 258434. https://doi.org/10.1155/2012/258434

Jørgensen, L.V., Madsen, H.L., Thomsen, M.K., Dragsted, L.O. and Skibsted, L.H. (1999). Regeneration of phenolic antioxidants from phenoxyl radicals: an ESR and electrochemical study of antioxidant hierarchy. Free Radical Research, 30 (3), 207-220. https:// doi.org/10.1080/10715769900300231

Kaczmarski, M., Wójcicki, J., Samochowiec, L., Dutkiewicz, T. and Sych, Z. (1999). The influence of exogenous antioxidants and physical exercise on some parameters associated with production and removal of free radicals. Die Pharmazie, 54(4), 303306.

Kirtikar, K.R. and Basu, B.D. (2006). Indian medicinal plants., p. 993-994. Dorchester, United Kingdom: Chesil Books.

Kouamé, P.B.K., Jacques, C., Bedi, G., Silvestre, V., Loquet, D., Barillé-Nion, S., Robins, R.J. and Tea, I. (2013). Phytochemicals isolated from leaves of Chromolaena odorata: impact on viability and clonogenicity of cancer cell lines. Phytotherapy Research, 27(6), 835-840. https://doi.org/10.1002/ ptr.4787

Ling, B., Zhang, M., Kong, C., Pang, X. and Liang, G. (2003). Chemical composition of volatile oil from Chromolaena odorata and its effect on plant, fungi and insect growth. Ying Yong Sheng Tai Xue Bao, 14 (5), 744-746. [In Chinese].

Lingga, L. (2012). The healing power of antioxidant. Jakarta, Indonesia: Elex Media Komputindo.

Lohézic-Le Dévéhat, F., Bakhtiar, A., Bezivin, C., Amoros, M. and Boustie, J. (2002). Antiviral and cytotoxic activities of some Indonesian plants. Fitoterapia, 73(5), 400-405. https:// doi.org/10.1016/S0367-326X(02)00125-9

Madhu (2018). Difference Between Paired and Unpaired Electrons: What are Unpaired Electrons?. Retrieved on September 12, 2018 from Website: https:// www.differencebetween.com/difference-betweenpaired-and-unpairedelectrons/\#: :text $=$ When $\%$ $20 \mathrm{an} \% \quad 20$ atom $\%$ 20or\% $20 \mathrm{a}$, an $\% 20$ unpaired $\%$ 20electron\%20is\%20unstable.

Maji, S., Dandapat, P., Ojha, D., Maity, C., Halder, S.K., Mohapatra, P.D., Pathak, T.K., Pati, B.R., Samantaa, A. and Mondal, K.C. (2010). In vitro antimicrobial potentialities of different solvent extracts of ethnomedicinal plants against clinically isolated 
human pathogens. Journal of Phytology, 2(4), 2126.

Manicam, C., Abdullah, J.O., Tohit, E.R.M., Seman, Z., Chin, S.C. and Hamid, M. (2013). In vitro anticoagulant activities of Melastoma malabathricum Linn. aqueous leaf extract: A preliminary novel finding. Journal of Medicinal Plants Research, 4(14), 1464-1472.

Naidoo, K.K., Coopoosamy, R.M. and Naidoo, G. (2011). Screening of Chromolaeana odorata (L.) King and Robinson for antibacterial and antifungal properties. Journal of Medicinal Plants Research, 5 (19), 4859-4862.

Odutayo, F., Ezeamagu, C., Kabiawu, T., Aina, D. and Mensah-Agyei, G. (2017). Phytochemical screening and antimicrobial activity of Chromolaena odorata leaf extract against selected microorganisms. Journal of Advances in Medical and Pharmaceutical Sciences, 13(4), 1-9. https://doi.org/10.9734/ JAMPS/2017/33523

Oladipupo, A.A. (2014). Preliminary Phytochemical Screening and Antioxidant Activity of Ethanolic Leave Extract of Azadirachta indica. IOSR Journal of Applied Chemistry, 7(4), 46-49. https:// doi.org/10.9790/5736-07424649

Onkaramurthy, M., Veerapur, V.P., Thippeswamy, B.S., Reddy, T.M., Rayappa, H. and Badami, S. (2013). Anti-diabetic and anti-cataract effects of Chromolaena odorata Linn., in streptozotocininduced diabetic rats. Journal of Ethnopharmacology, 145(1), 363-372. https:// doi.org/10.1016/j.jep.2012.11.023

Pandith, H., Zhang, X., Thongpraditchote, S., Wongkrajang, Y., Gritsanapan, W. and Baek, S.J. (2013). Effect of Siam weed extract and its bioactive component scutellarein tetramethyl ether on antiinflammatory activity through NF- $\mathrm{kB}$ pathway. Journal of Ethnopharmacology, 147(2), 434-441. https://doi.org/10.1016/j.jep.2013.03.033

Parivuguna, V. (2008). Antimicrobial Properties and Phytochemical Constituents of Rheo discolour Hance. Ethnobotanical Leaflets, 12, 841-845.

Phan, T.T., Wang, L., See, P., Grayer, R.J., Chan, S.Y. and Lee, S.T. (2001). Phenolic compounds of Chromolaena odorata protect cultured skin cells from oxidative damage: implication for cutaneous wound healing. Biological and Pharmaceutical Bulletin, 24(12), 1373-1379. https://doi.org/10.1248/ bpb.24.1373

Pisoschi, A.M., Pop, A., Cimpeanu, C. and Predoi, G. (2016). Antioxidant capacity determination in plants and plant-derived products: A review. Oxidative medicine and cellular longevity, 2016, 9130976.

\section{https://doi.org/10.1155/2016/9130976}

Prior, R.L., Wu, X. and Schaich, K. (2005). Standardized methods for the determination of antioxidant capacity and phenolics in foods and dietary supplements. Journal of Agricultural and Food Chemistry, 53(10), 4290-4302. https:// doi.org/10.1021/jf0502698

Putri, D.A. and Fatmawati, S. (2019). A New Flavanone as a Potent Antioxidant Isolated from Chromolaena odorata L. Leaves. Evidence-Based Complementary and Alternative Medicine, 2019, 1453612. https:// doi.org/10.1155/2019/1453612

Riaz, T., Abbasi, A.M., Shahzadi, T., Ajaib, M. and Khan, M.K. (2012). Phytochemical screening, free radical scavenging, antioxidant activity and phenolic content of Dodonaea viscosa. Journal of the Serbian Chemical Society, 77(4), 423-435. https:// doi.org/10.2298/JSC110621183R

Richardson, P.M. (1990). Phytochemical methods: a guide to modern techniques of plant analysis. Brittonia, 2(42), 115-115. https:// doi.org/10.2307/2807624

Sembiring, E.N., Elya, B. and Sauriasari, R. (2018). Inhibitory Effect on Arginase and Total Phenolic Content Determination of Extracts from Different parts of Melastoma malabathricum L. Journal of Young Pharmacists, 10(2S), S114-S117. https:// doi.org/10.5530/jyp.2018.2s.23

Shekhar, T.C. and Anju, G. (2014). Antioxidant activity by DPPH radical scavenging method of Ageratum conyzoides Linn. leaves. American Journal of Ethnomedicine, 1(4), 244-249.

Stanley, M.C., Ifeanyi, O.E., Nwakaego, C.C. and Esther, I.O. (2014). Antimicrobial effects of Chromolaena odorata on some human pathogens. International Journal of Current Microbiology and Applied Sciences, 3(3), 10061012.

Sulistyaningrum, I.F., Sofiratmi, W. and Renalta, W.D. (2018). Antibacterial Activities of Ethanol Extract of Karamunting (Melastoma malabathricum L.) Leaf and Flowers on Salmonella typhi, Escherichia coli, Staphylococcus aureus presented at the Proceedings of BROMO Conference, p. 316-318. Surabaya, Indonesia. https:// doi.org/10.5220/0008362003160318

Sunilson, J.A.J., Anandarajagopal, K., Kumari, A.V.A.G. and Mohan, S. (2009). Antidiarrhoeal activity of leaves of Melastoma malabathricum Linn. Indian Journal of Pharmaceutical Sciences, 71(6), 691-695. https://doi.org/10.4103/0250-474X.59556

Susanti, D., Sirat, H.M., Ahmad, F., Ali, R.M., Aimi, N. 
and Kitajima, M. (2007). Antioxidant and cytotoxic flavonoids from the flowers of Melastoma malabathricum L. Food Chemistry, 103(3), 710-716. https://doi.org/10.1016/j.foodchem.2006.09.011

Tiwary, B. K., Bihani, S., Kumar, A., Chakraborty, R. and Ghosh, R. (2015). The in vitro cytotoxic activity of ethno-pharmacological important plants of Darjeeling district of West Bengal against different human cancer cell lines. BMC Complementary and Alternative Medicine, 15, 22. https://doi.org/10.1186/ s12906-015-0543-5

Evans, W.C., Evans, D. and Treas, G.E. (Eds.) (2002). Trease and Evans' pharmacognosy. $15^{\text {th }}$ ed. New York, USA: Saunders Publishers.

Usunomena, U. and Efosa, E.G. (2016). Phytochemical analysis, mineral composition and in vitro antioxidant activities of Chromolaena odorata leaves. ARC Journal of Pharmaceutical Sciences, 2 (2), 16-20. https://doi.org/10.20431/24551538.0202003

Walton, N.J. and Brown, D.E. (Eds.) (1999). Chemicals from plants. Perspectives on plant secondary products. Singapore: World Scientific Publishing Co Pte Ltd. https://doi.org/10.1142/3203

Yoshida, T., Nakata, F., Hosotani, K., Nitta, A. and Okuda, T. (1992). Dimeric Hydrolysable Tannin from Melastoma malabathricum. Phytochemistry, 31 (8), 2829-2833. https://doi.org/10.1016/0031-9422 (92)83641-B

Zakaria, Z.A., Raden Mohd. Nor, R.N.S., Hanan Kumar, G., Abdul Ghani, Z.D.F., Sulaiman, M.R., Rathna Devi, G., Mat Jais, A.M., Somchit, M.N. and Fatimah, C.A. (2006). Antinociceptive, antiinflammatory and antipyretic properties of Melastoma malabathricum leaves aqueous extract in experimental animals. Canadian Journal of Physiology and Pharmacology, 84(12), 1291-1299. https://doi.org/10.1139/y06-083

Zhang, L. and Xu, J.G. (2015). Comparative study on antioxidant activity of essential oil from white and black pepper. European Journal of Food Science and Technology, 3(3), 10-16.

Zimdahl, R.L. (2007). Weeds: the beginning. In Fundamentals of Weed Science. $5^{\text {th }}$ ed., p. 17-46. USA: Academic Press. 